\title{
THE HISTORY OF "TUAN \\ SEBERANG" (TUN SERI LANANG) \\ BASED ON ACEH AND DUTCH \\ SOURCES
}

\author{
[Sejarah “Tuan Seberang” (Tun Seri Lanang) Berdasarkan \\ Sumber Aceh dan Belanda]
}

\author{
M. Adli Abdullah
}

bawarith@gmail.com

Universitas Syiah Kuala Darussalam, Banda Aceh, Indonesia.

Azmi Arifin

azmiarifiin@usm.my

School of Humanities, Universiti Sains Malaysia, Malaysia.

\begin{abstract}
This study discusses the position of Tuan Seberang, a prominent figure of the Malay Peninsula, who was immensely influential in shaping the kingdom of Aceh Darussalam in the 17th century. His prominence was evident when the book of Aceh's historiography, Ma Bain-as-Salatin, clearly showed the position of and role played by Tuan Seberang in the administration of this kingdom. However, to date, there are rarely historians who have actually examines the position and prominence of Tuan Seberang, either when he was in Aceh or in the Peninsula. To be sure, Tuan Seberang was a prominent figure who was highly respected by the Portuguese and Dutch because of his huge contribution to the administration of this kingdom during the reign of Sultan Iskandar Muda (1607-1636), Sultan Iskandar Thani (1636-1641) and Sultan Safiatuddin Syah (1641-1675). In this study, the author examines the issue of who Tuan Seberang really was, the role he played, his contribution and his relationship with the rulers and Aceh's political figures.
\end{abstract}


Keywords: Tuan Seberang, Tun Seri Lanang, Sulalat-us-Salatin, Ma Bainas-Salatin, The Kingdom of Aceh Darussalam

\begin{abstract}
Abstrak
Kajian ini membincangkan kedudukan Tuan Seberang, tokoh Melayu Semenanjung, yang sangat berpengaruh dalam perkembangan Kerajaan Aceh Darussalam pada kurun ke-17. Ketokohannya terbukti apabila karya historiografi Aceh, Ma Bain-as-Salatin dengan jelas memerihalkan kedudukan dan peranan yang dimainkan oleh Tuan Seberang dalam pentadbiran kerajaan itu. Namun sehingga kini, jarang terdapat ahli sejarah yang benar-benar meneliti kedudukan dan peranan Tuan Seberang secara khusus, sama ada semasa beliau berada di Aceh atau di Semenanjung. Padahal Tuan Seberang merupakan seorang tokoh terkemuka yang sangat dihormati oleh Portugis dan Belanda kerana sumbangan besarnya kepada pentadbiran kerajaan tersebut semasa pemerintahan Sultan Iskandar Muda (1607-1636), Sultan Iskandar Thani (1636-1641) dan Sultan Safiatuddin Syah (1641-1675). Dalam kajian ini, penulis meneliti tentang persoalan siapa sebenarnya Tuan Seberang dalam sejarah Aceh, peranan dan sumbangannya serta hubungannya dengan para pemerintah dan tokoh politik Aceh.
\end{abstract}

Kata kunci: Tuan Seberang, Tun Seri Lanang, Sulalat-us-Salatin, Ma Bainas-Salatin, Kerajaan Aceh Darussalam

\title{
INTRODUCTION
}

In Aceh's historiography, there were prominent figures who were immensely influential in the royal circle of the kingdom of Aceh in the 17th century. Among them were Syeikh Syamsuddin as-Sumatrani, Syeikh Hamzah Fansuri, Syeikh Nurudin ar-Raniry, Syeikh Abdurrauf al-Fansuri as-Singkili, ${ }^{1}$ and Orang Kaya Seri Paduka Tuan Seberang, or popularly known as "Tuan Seberang". The roles played by these prominent figures have been extensively examined by scholars in the disciplines of history, religion, literature and law. However, the position of and role played by Tuan Seberang in the administrative history of this kingdom has yet to be studied in great depth. ${ }^{2}$ In fact, in terms of his position and role, Tuan Seberang was clearly an important figure as shown in the manuscript Ma Bain-as-Salatin, ${ }^{3}$ one of the magnificent Malay manuscripts ever written in the 17 th century that used the title as-Salatin (لسعبطيت). ${ }^{4}$ 


\section{MANUSCRIPT OF $M A B A I N-A S-S A L A T I N$ AND TUAN SEBERANG}

In Aceh's historiography, the manuscript Ma Bain-as-Salatin was also known by other titles and names. Among them was Adat Meukata Alam, because this manuscript was believed to have been produced during the reign of Sultan Iskandar Muda Meukata Alam, who, after his demise, was conferred the title Poe Teumeurehom (the late Sultan). In another historiographic source of Aceh, known as Hadih Mmaja, ${ }^{5}$ it was stated that:

Adat Bak Poe Teumeureuhom

Hukum Bak Syiah Kuala

Qanun Bak Putroe Phang

Reusam Bak Laksamana.

[Rules in the hands of Poe Teumeureuhom

(Islamic) laws in the hands of ulama

Laws in the hands of Puteri Pahang

The enforcement under the power of Laksamana.]

In terms of its background, Ma Bain-as-Salatin was believed to have been compiled during the reign of Sultan Iskandar Muda; however, later it was improved and reproduced by this ruler's successor. The contents of the manuscript Ma Bain-as-Salatin were organised into various sections, comprising the Command of all the Rulers, Genealogy of the Aceh Rulers, Traditions of the Council of Rulers, Register of the Country's Tax Tradition and Trading Ships, amounting to 176 pages written in Arab-Jawi script using Malay language. In the introduction of the manuscript's third section titled Adat Majelis Raja-raja (the Traditions of the Council of Rulers), it was mentioned that Sultanah Safiatuddin Syah requested that the manuscript Ma Bain-as-Salatin be reproduced, and most likely with the intention of ensuring that this legal manuscript of the kingdom of Aceh be revised by "Tuan Seberang" as mentioned as follows: 


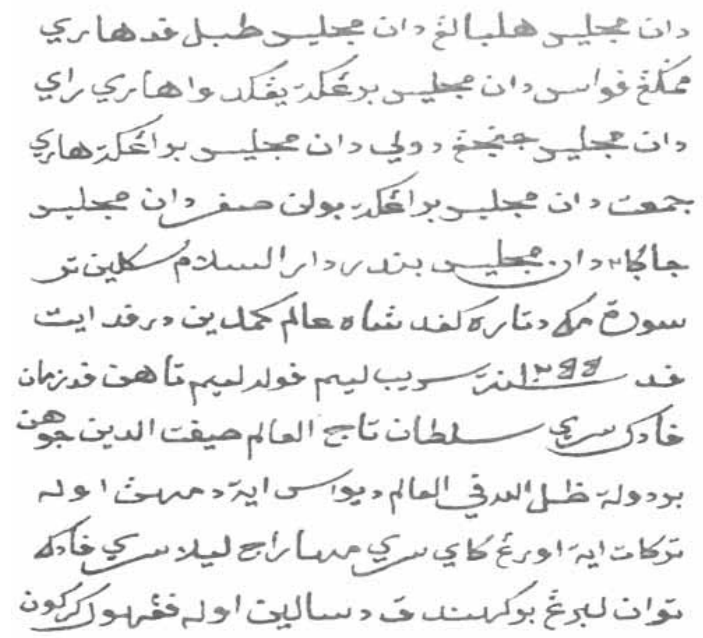

Dan majlis hulubalang dan majlis tabal pada hari memegang [sic; makmengang] puasa dan majlis berangkat yang kedua Hari Raya dan majlis junjung duli dan majlis berangkat hari Jum 'at dan majlis berangkat bulan Safar dan majlis jaga-jaga dan majlis Bandar Darussalam sekalian tersurat maka ditaruh kepada Syah Alam. Kemudian daripada itu pada sanat 1055, seribu lima puluh lima tahun, pada zaman Paduka Seri Sultan Tajul Alam Sifatuddin [sic; Safiatuddin] Juhan Berdaulat zillullahi fil alam, dewasa itu dimohon oleh tarakata itu Orang Kaya Seri Maharaja Lela Seri Paduka Tuan Seberang, berkehendak disalin oleh penghulu kerukun.

[... and regulations for the military chiefs, regulations for the inauguration of the day preceding the fasting month, regulation for the procession to the mosque for the two feast days, regulation for making obeisance to the king, regulations for the procession to the mosque on Friday, regulations for the procession in the month of Safar, regulations for the vigil and regulations for the port of Aceh Darussalam. All these are written and kept in the possession of the king. Then in 1055 H (1645 A.D) during the reign of Paduka Seri Sultan Tajul Alam Safiatuddin Johan Berdaulat Zilullah fil Alam, Orang Kaya Seri Maharaja Lela Seri Paduka Tuan Seberang requested that the regulations which have been written to be copied by the Penghulu Karkun. $\left.{ }^{6}\right]$

Secondly, the name and role of Tuan Seberang can also be seen through the kingdom's hierarchical structure of dignitaries, that is in terms of his position as the fourth nobility during the reign of Aceh's Sultanah Safiatuddin Syah, as explained in Ma Bain-as-Salatin: 


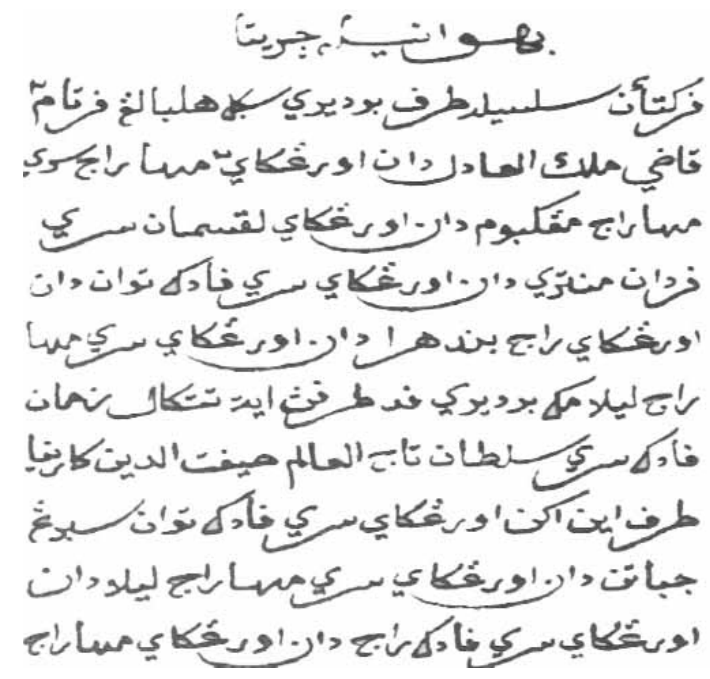

Bahawa inilah cerita perkataan salasilah taraf berdiri segala hulubalang, pertama-tama "Kadhi Malikul Adil" dan "Orang Kaya Maharaja Seri Maharaja Mangkubumi" dan "Orang Kaya Laksamana Seri Perdana Menteri dan Orang Kaya Seri Paduka Tuan" dan "Orang Kaya Raja Bendahara dan Orang Kaya Seri Maharaja Lela", maka berdiri pada tarafnya itu tatkala zaman Paduka Seri Sultan Tajul Alam Sifatuddin [sic; Safiatuddin] karunia taraf ini akan Orang Kaya Seri Paduka Tuan Seberang Jabatan dan Orang Kaya Seri Maharaja Lela dan Orang Kaya Seri Paduka Raja dan Orang Kaya Maharaja.

[The following is the hierarchical order of functionaries of the military chiefs: First, Qadhi Malikul Adil, then Orang Kaya Maharaja Seri Maharaja Mangkubumi, and Orang Kaya Laksamana Seri Perdana Menteri, and Orang Kaya Seri Paduka Tuan, and Orang Kaya Raja Bendahara and Orang Kaya Seri Maharaja. The following is the hierarchical order of functionaries during the reign of Paduka Seri Sultanah Tajul Alam Safiatuddin which gives the position of Orang Kaya Empat to Orang Kaya Seri Paduka Tuan Seberang and Orang Kaya Seri Maharaja Lela and Orang Kaya Seri Paduka Raja and Orang Kaya Maharaja". $\left.{ }^{7}\right]$

Thirdly, it was also expressed in Ma Bain-as-Salatin that Tuan Seberang apart from being the fourth nobility, his name also appeared in the eighth nobility list together with other dignitaries. As mentioned in the manuscript Ma Bain-as-Salatin. 


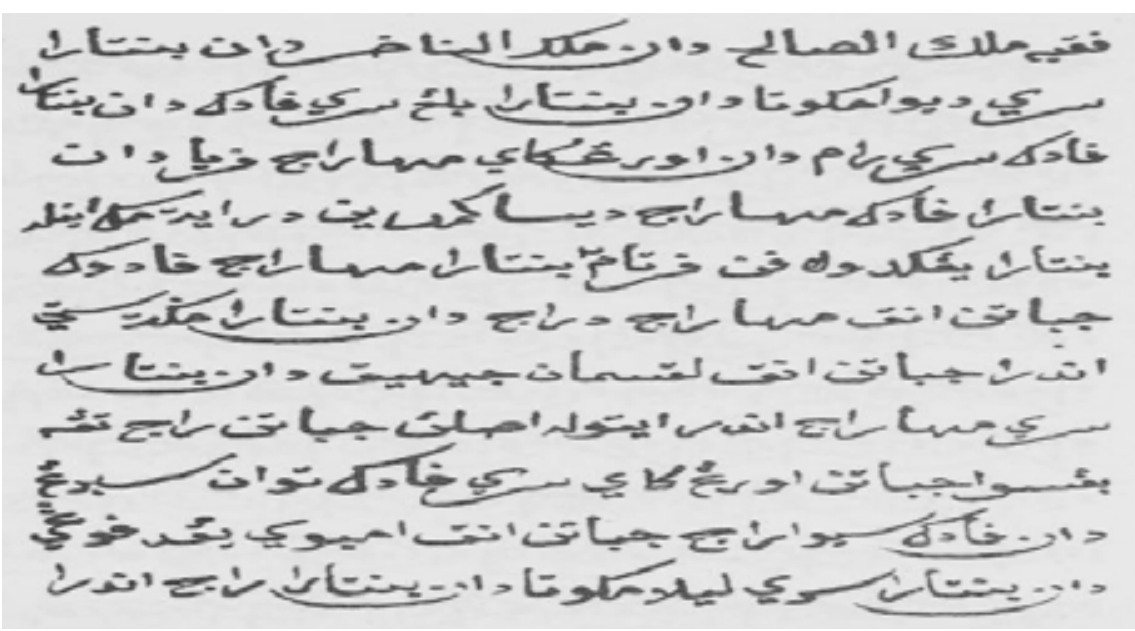

Kemudian dari itu maka inilah bentara yang kedelapan; pertama-tama Bentara Maharaja Paduka jabatan anak Maharaja Diraja dan Bentara Megat Sati Indera jabatan anak Laksamana Shik dan Bentara Seri Maharaja Indera itulah asalnya jabatan, Raja Tengah Bungsu jabatan Orang Kaya Seri Paduka Tuan Seberang dan Paduka Siwa Raja jabatan anak Ambui yang di Punge dan Bentara Lela Seri Makota dan Bentara Raja Indera Makota jabatan Tun Mardukuh Ratna dan Bentara Paduka Dewa Indera.

[... the eight Bentara: First the position of Bentara Maharaja Paduka son of Maharaja Diraja, then the position of Bentara Megat Setia Indera son of Laksamana Jihik and Bentara Seri Maharaja Indera, his real position being Raja Tengah bungsu, Orang Kaya Seri Paduka Tuan Seberang and Paduka Siwa Raja jabatan son of Amboi at Punge and Bentara Seri Lela Meukuta and Bentara Raja Indera. ${ }^{8}$ ]

Fourthly, during the reign of Sultanah Safiatuddin Syah, Tuan Seberang was also entrusted by the sultanah of Aceh to play the role of Panglima Bandar (Port Master), a position which was synonymous with the presentday Minister of Finance as stated in the manuscript of Ma Bain-as-Salatin as follows: 


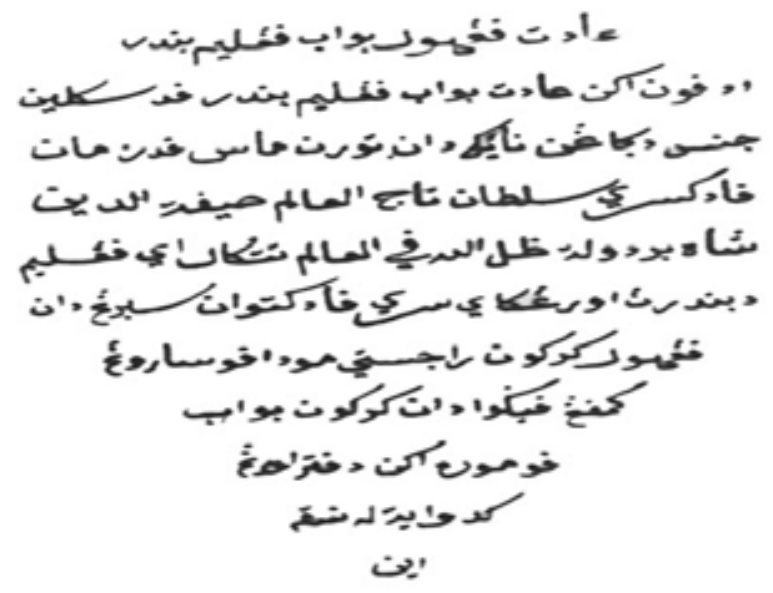

Adat Penghulu Bawab Panglima Bandar

Adapun akan adat bawab Panglima Bandar pada sekalian jenis dagangan, naik dan turun masa pada zaman paduka Seri Sultan Tajul Alam Sifatuddin [sic; Safiatuddin] Syah berdaulat dhilullah fil alam tatkala ia panglima dibandarnya [sic; Panglima Bandar] Orang Kaya Paduka Tuan Seberang dan penghulu keureukun raja setia muda po sarong kampung Pigu dan keureukun bawab po Meurah akan daftar orang kedua itulah naskah ini”.

[The duties of the porter of the Panglima Bandar: The duties given to the porter of the Panglima Bandar are levied for loading and unloading all kinds of goods, during the reign of Paduka Seri Tajul Alam Safiatuddin Syah Dhilullah fil Alam, when Orang Kaya Seri Paduka Tuan Seberang became the Panglima Bandar, Penghulu Karkun Raja Setia Muda Po Sarong from Pingu village and Karkun Bawab Po Meurah listed the dutiable merchandise as follows. $\left.{ }^{9}\right]$

The explanation of Ma Bain-as-Salatin regarding some positions and the function held by Tuan Seberang in the administration of the kingdom of Aceh Darussalam showed that Tuan Seberang was someone who was extremely influential and gained a special position in particular at the height of the glory of this kingdom's political power.

Apart from clarifying his position in Ma Bain-as-Salatin, Tuan Seberang's position was also mentioned in another important reference source of the kingdom of Aceh, i.e. Sarakata Samalanga (Royal Edicts) ${ }^{10}$ produced by Sultan Iskandar Muda in $1613 \mathrm{M}$, and ordered to be reproduced in 1055 Hijriah (1645) by Sultanah Safiatuddin Syah. In that manuscript, it was stated that: 

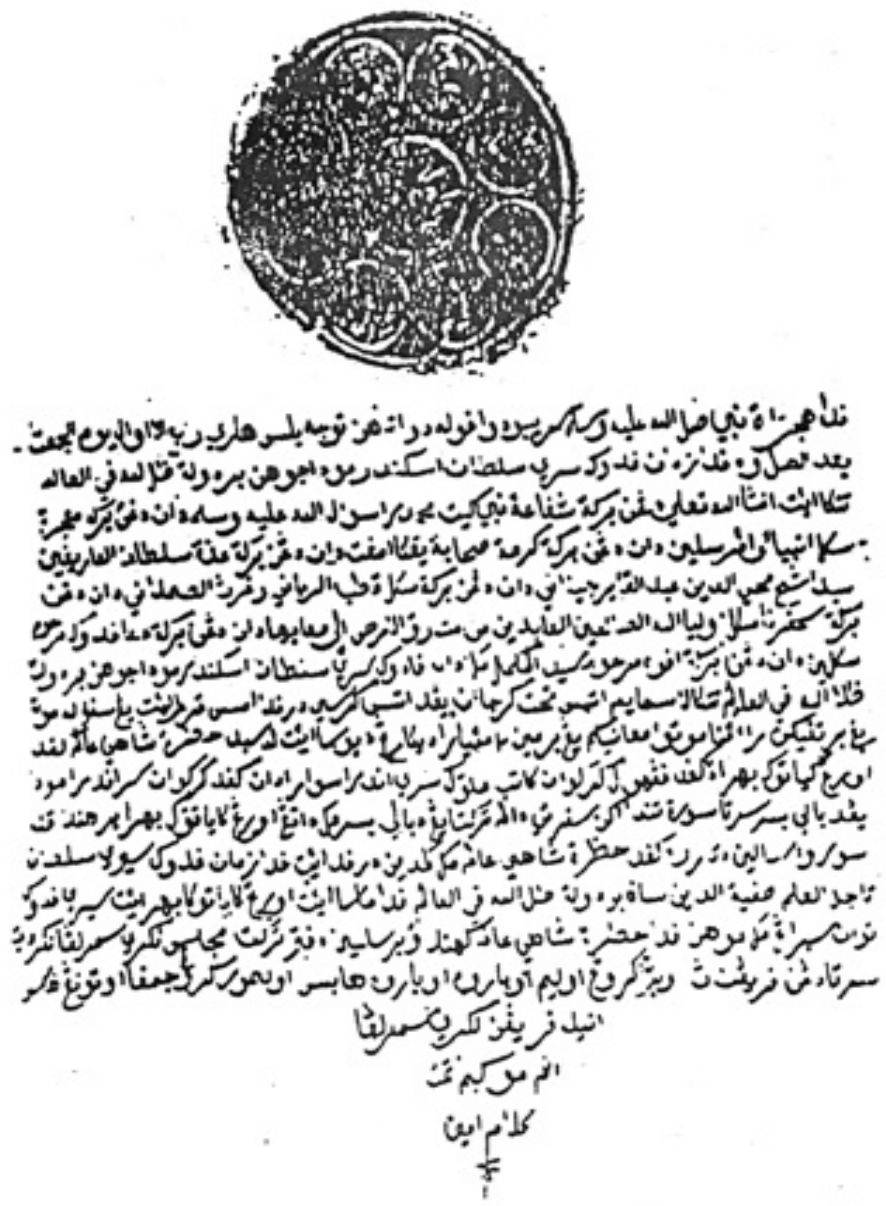

Pada hijrat Nabi sallallahu alaihi wasallam seribu dua puluh dua tahun, tujuh belas hari Rabiul al awwal yaum al jum 'ah ba'da salat pada zaman Paduka Seri Sultan Iskandar Muda Johan berdaulat zillallah fil al alam, tatkala itu insyaAllah taala dengan berkat syafa'at Nabi kita Muhammad Rasul Allah [sallallahu] alaihi wasallam dan dengan berkat segala ambiya walmursalin dan dengan berkat keramat sahabat yang keempat dan dengan berkat 'izzat Sultan al Arifin Sayyid Syeikh Muhyi al-Din Abdu al Qadir Jilani dan dengan berkat segala qutb al rabbani wa ghawth al samadani dan dengan berkat sempurna segala aulia Allah as shalihin wal abidin min masyarikil ardh ila maghaaribiha dan dengan berkat doa paduka marhum sekalian dan dengan berkat apuah marhum sayyid al Mukammal. Maka adalah paduka Seri Sultan Iskandar Muda Johan berdaulat Zillallah Fil alam tatkala semayam atas 
takhta kerajaan yang di atas kerusi daripada emas itu yang sepuluh mutu yang bertepikan ratna mutu manikam yang berumbai-rumbai mutiara di kala dewasa itulah sabda hadrat syahi alam kepada Orang Kaya Tuk Bahra [sic: Datuk Bendahara] dan kepada Penghulu Kereukun Katibul Muluk Seri Indera Sura dan kepada Karkun Seri Indera Muda yang di balai besar serta surat tanda akan seperti dalam sarakata yang di balai besar. Maka datang Orang Kaya Datuk Bahra berhendaklah surat salin ditaruh [sic: diberikan] kepada hadrat Syahi Alam. Maka kemudian daripada itu pada zaman Paduka Seri Sultan Taj al Alam Safiyyat al Din Syah berdaulat zill Allah fi alam pada masa itulah Orang Kaya Tuk Bahra Seri Paduka Tuan Seberang, maka mohon hadharat Shahi Alam kehendak bersalin daftar sarakata Majlis negeri Samarlanga negerinya serta dengan perenggannya [sic: batasannya] u barat krueng [sic: sungai] Ulim u baroh [sic: utara] u baroh habeh [sic: seluruhnya] u timu [sic: timur] krueng Jeumpa, u tunong [sic: selatan] habeh. Inilah perenggan negeri Samarlanga enam mukim. Tamat kalam amin.

[At the time of hijrah Prophet (Muhammad) sallallahu alaihi wasallam one thousand twenty two years, seventeen days Rabiul-al awwal on the day of Friday after prayer, during the time of Sultan Iskandar Muda Johan berdaulat zillallah fil al-alam, InsyaAllah Taala with the blessing of intercession (syafaat) from our Prophet Muhammad the Messenger of God alaihi wasallam and with the blessing of all the messengers and thanks to the four friends (sahabah) and 'izzat Sultan Al-Arifin Sayyid Syeikh Muhyi Al-Din Abdu al-Qadir Jilani and of al-qutb al-rabbani wa ghawth al-samadani and with all the blessings of waliullah as shalihin wal abidin min masyarikil ardh ila maghaaribiha and with all prayers and blessings of peace be upon (Sultan) al-Mukammal. So is the court of the Sultan Iskandar Muda Johan sovereign of zillallah fil alam, when heading towards the royal throne on the ten-seated gold and pearl-tipped seat in his adulthood is the word of the Shah Alam (Iskandar Muda) to the Orang Kaya Tuk Bahra [sic: Datuk Bendahara] and to the Head of the Head of Katibul Muluk Seri Indera Sura and Karkun Seri Indera Muda who are in the hall and the letter will be as in the words of the big hall. So came the Orang Kaya Datuk Bahra to have a copy of his decree [sic: given] to the wish of Syahi Alam. Then in the days of Sultan Taj al-Siddiq al-Safiyyat al-din Syah berdaulat zill Allah fi alam at that time the Orang Kaya Tuk Bahra Seri Paduka Tuan Seberang, then to make a request to Shah Alam the wish to bear the list of the state's Samarlanga state Council's parishes and with its border, to the west Ulim river to the north unlimited, to the east Jeumpa river, to the south unlimited. This is the border of the state Samarlanga which consists of six mukims. End. Amin. $\left.{ }^{11}\right]$

The authenticity of Sarakata Samalanga was verified by G. Tichelman, ${ }^{12}$ a Dutch government officer who used to work in Aceh during colonial 
rule. Aboe Bakar in his book, Sebuah Sarakata Kerajaan Aceh, ${ }^{13}$ explained that Tichelman obtained Sarakata Samalanga from Teuku Raja Sabi, the eldest son of Teuku Ubiet son of Teuku Peureudan, the legitimate heir of Tuan Seberang who was made the ruler of Samalanga (now situated at Kabupaten Biruen Aceh). However, since Teuku Ubiet sided with Sultan Muhammad Daud Syah (1878-1939) when the sultan was in conflict with the Dutch-elected sultan, the Tuan Seberang's heirs had been banished by the Dutch to Batavia (Jakarta).

\section{THE ORIGINS OF "TUAN SEBERANG"}

Normally, a prominent figure's real name in Aceh is seldom mentioned although he may be referred to as "habib". A person was usually referred to in terms of his place of origin. For example, Teungku Yaman, Teungku Madinah, Teungku Chik in Tiro, Teungku Chik Awe Geutah, Teungku Chik Paya Bakong, Teungku Chik in Cot Plieng, Teungku Chik in Subung, Teungku Chik in Meurah, Teungku Chik in Lueng Kubeu, Teungku Chik Samalanga, Teungku in Kuta etc. ${ }^{14}$ Likewise, Tuan Seberang was a mere appellation showing that he hailed from "seberang". Given this scenario, one question arises at this point in time, what then is the meaning of "seberang"? Who was Tuan Seberang actually and where was his place of origin? Takeshi Ito, a Japanese scholar, who had substantially examined a number of aspects of Aceh's history, also tried to demystify Tuan Seberang's public standing. ${ }^{15}$ In his study, Ito said that Tuan Seberang was a high-ranking official in the kingdom of Aceh Darussalam in the 17th century and his origin was the Malay Peninsula. According to Ito, the appellation "seberang" referred to the states in the Malay Peninsula which were bordered by the sea with Aceh ${ }^{16}$ and the name Tuan Seberang indicated Tuan Seberang's origin that is the kingdom of Perak. ${ }^{17}$

Another scholar who was equally interested in studying this issue was Tichelman himself. Tichelman also examined the authenticity of the manuscript Sarakata Samalanga which was owned by uleebalang (hulubalang) Samalanga. ${ }^{18}$ According to Tichelman, it was stated in the manuscript that the kingdom of Samalanga was presented by the palace of Aceh to the Tuan Seberang, and his heir. To Tichelman, Tuan Seberang was a high ranking official from the state of Melaka [Johor] who was captured and then brought to Aceh. ${ }^{19}$ Hence to Tichelman's understanding, Tuan Seberang was Tun Seri Lanang, i.e. Johor's Vizier (Bendahara) who was brought to Aceh in $1613 .{ }^{20}$ 
In this regard, some parties attempted to explain how Tun Seri Lanang was brought to Aceh. For instance, it was said that this happened because of the policy of transferring the inhabitants of the Peninsula on a large scale to Aceh by the ruler of Aceh during Aceh's conflict with a number of Malay states, among them Johor, Perak, Kedah and Pahang, a view that was supported by W. Linehan in his study. According to Linehan, "the whole territory of Acheh was almost depopulated by war. The king endeavoured to repeople the country by his conquests. Having ravaged the kingdoms of Johor, Pahang, Kedah, Perak and Deli, he transported the inhabitants from those places to Aceh to the number of twenty-two thousand people". ${ }^{21}$ This incident occurred when the kingdom of Aceh was ruled by Sultan Iskandar Muda (1607-1636).

Ma Bain-as-Salatin and Sarakata Samalanga explained the role of Orang Kaya Tuan Seberang as a prominent figure in the kingdom of Aceh ever since the reign of Sultan Iskandar Muda till the ruling period of Sultanah Safiatuddin Syah. Based on the reference of Sarakata reproduced in $1644 \mathrm{M} / 1053 \mathrm{H}$, it clearly showed that Sultanah Safiatuddin Syah had resurrected and reconfirmed his position as Orang Kaya Datuk Bendahara Seri Paduka Tuan Seberang (according to Aceh's spelling, Tok Bahra) as Uleebalang or the King of Samalanga. The Datuk Bendahara itself was a title which was accepted by Tun Seri Lanang since he became Johor's Vizier before he was brought to Aceh, while the title Orang Kaya Seri Paduka Tuan Seberang was an honorary title in Aceh that was conferred on him by the ruler of Aceh soon after. ${ }^{22}$ In fact, the son of Tun Seri Lanang, i.e. Tun Rembau, who was also stated in Aceh's sources was appointed by Aceh's ruler to be the Commander of Aceh. ${ }^{23}$

In order to further fortify the evidence that Tuan Seberang or Datuk Bendahara or Tun Seri Lanang was actually brought from Johor to Aceh and then appointed as one of the prominent figures in Aceh, hence in the second version of Sarakata Samalanga published by Sultan Ibrahim Mansur Syah, 1251-1286 H (1836-1870 M) it was stated as follows:

Pada hijrah Nabi SAW 1285, seribu dua ratus lapan puluh limong [sic: lima] tahun, pada empat belas bulan Muharram, yaumu Jumat, pada malam itu, pada zaman Paduka Sri Sultan Ibrahim Mansur Syah, tatkala itulah insyaAllah Taala dan berkat syafaat Nabi kita Muhammad SAW dan dengan berkat mukjizat segala aulia wal mursalin dan dengan berkat indatu merureuhom sekalian, ba'da sembahyang Isya saat kerajaan di atas kursi mas kursani sijil 


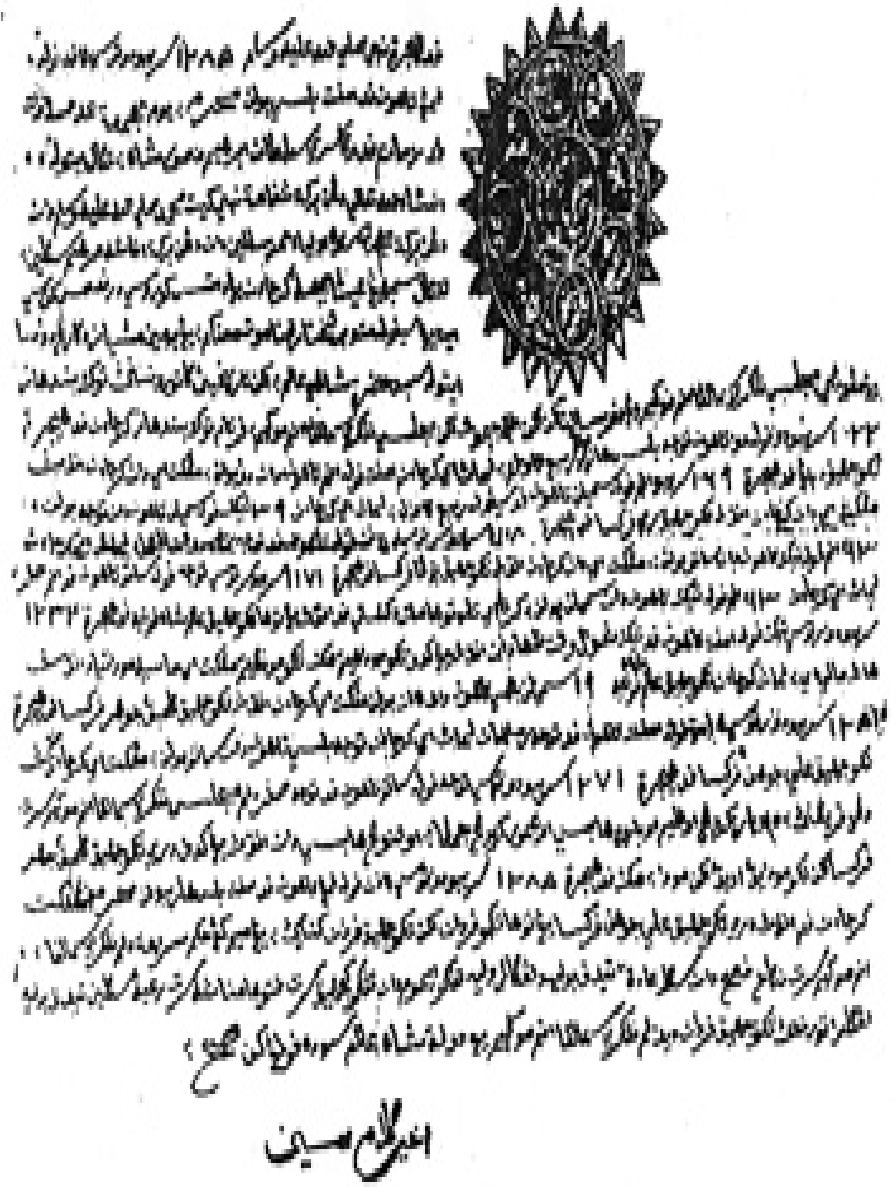

sepuluh mutu bertakhta1 rakna mutu manikam, yang bermain[an]2 mutiara dikarang. Dewasa itulah sabda Hadharat Syah Alam, akan tarikhinya3 keturunannya Tok Bendahara [sic: Tun Seri Lanang] yang mepunyai [sic: mempunyai] Majlis Nanggroe Samalanga VI Mukim dengan dipersalinkan akan anak cucunya akan Majlis Nanggroe Samalanga VI Mukim. Pertama Tok Bendahara, kerajaan pada Hijrah 1022 seribu dua puluh dua tahun tujuh sebelas hari bulan Rabiul Awwal. Lamanya ia kerajaan empat puluh enam tahun dan dua bulan, mangkat ia dan kerajaan anaknya Teuku Syik Di Blang pada hijrah 1069 seribu enam puluh sembilan tahun pada sepuluh Rabiul Awwal. Lamanya ia kerajaan 39 tiga puluh sembilan tahun tujuh bulan, mangkat ia dan kerajaan anaknya Teuku Syik Raja Perkasa pada hijrah 
1108 seribu seratus lapan tahun pada tujuh hari bulan Rabiul Akhir maka kerajaan [sic: kerajaannya] 63 tahun satu bulan, mangkat ia dan kerajaan anaknya Teuku Syik Muda Perkasa pada hijrah 1171 seribu seratus tujuh puluh satu tahun pada enam Safar, lamanya ia kerajaan 63 enam puluh tiga tahun dan sembilan bulan gerah ia telah tuha, maka diganti pada anaknya yang tuha Teuku Syik Alam Syah Puteh pada hijrah 1234 seribu dua ratus tiga puluh empat tahun pada tiga Syawal waktu Zhuha dan anaknya yang kedua Teuku Muda Hitam, maka Teuku Muda Hitam mangkat masih muda tiada anak saat mati, male [sic: mandul] ia. Lamanya kerajaan Teuku Syik Alam Syah Puteh 19 sembilan belas tahun dan lapan bulan, mangkat ia, kerajaan anaknya Teuku Syik Geumbak Jauhar Perkasa pada hijrah 1251 seribu dua ratus lima puluh satu tahun pada tujuh Rajab dan lamanya ia kerajaan tujuh belas tahun dan satu bulan, mangkat ia, [dan] kerajaan adindanya Teuku Syik Ali Johan Perkasa pada hijrah 1271 seribu dua ratus tujuh puluh satu tahun pada tujuh safar dalam Majlis Nanggroe Samalanga VI Mukim serta dalam peringan-peringannya4: U Barat Krueng Ulim, U Baroh habeh5, U Timu Krueng Jeumpa, U Tunong habeh6. Dan anaknya yang kedua dari Teungku Syik Geumbak Johar Perkasa akan Teuku Muda Nyak Adek akan muda. Maja pada hijrah 1285 seribu dua ratus lapan puluh limong (lima) tahun pada empat belas hari bulan Muharram ia mangkat, [maka] kerajaan[lah] pada anaknya dari Teuku Syik Ali Johan Perkasa yang tuha [yaitu] Teuku Fardan akan Teuku Syik Fardan gantinya, yang memegang hukum syariat dalam Nanggroe Samalanga VI Mukim, serta nikah, fashakh dan talak. Adat tidak boleh dilanggar daleh Teungku Imum dan Teungku Geusyik serta Peutuha Meunasah serta rakyat sekalian tidak boleh langgar aturannya Teuku Syik Fardan di dalam Nanggroe Samalanga VI Mukim yang Daulat Syah Alam (Iskandar Muda - Peneliti) sudah pulangkan shah. Akhir kalam. Amin.

[At the hijrah of the Prophet SAW 1285, one thousand two hundred and eighty-five years, on fourteenth of Muharram, on Friday night, in the days of Majesty Sri Sultan Ibrahim Mansur Syah, when it is Allah Taala willing and by the intercession (syafaat) of our Prophet Muhammad SAW and with the blessings of the miracles of all saints and messengers of God and with all the blessings of our forefathers. After isya prayer the pearly throne of ten certificates of quality was formed. That is the word of Hadharat Syah Alam regarding his descendant of Tok Bendahara [sic: Tun Seri Lanang] who possesses the Majlis Nanggroe Samalanga VI Mukim with the dissolution of his grandson of Nanggroe Samalanga VI Mukim. First Tok Bendahara, his reign in Hijrah a thousand twenty two years and eleven days of the month of Rabiul Awwal. It has been a lengthy reign of forty-six years and two months, his death and the kingdom of his son Teuku Syik Di Blang in hijrah thousand sixty-nine years in ten Rabiul Awwal. The kingdom lasted 
for thirty-nine nine and seven months, his death and the kingdom of his son Teuku Syik Raja Perkasa in the hijrah of one thousand one hundred and eight years on the seventh day of the month of Rabiul Akhir; the kingdom existed for sixty-three years and one month, Teuku Syik Muda Perkasa on the hijrah one hundred and seventy-one years on six Safar, being old sixty-three years old and nine months because of old age he was replaced by his son Teuku Syik Alam Syah Puteh at the hijrah thousand two hundred thirty-four years in three Shawal time when Zhuha and his second son Teuku Muda Hitam, then Teuku Muda Hitam died young leaving no progeny as he was barren. It was a lengthy reign of nineteen years and eight months, the government of his son Teuku Syik Geumbak Jauhar Perkasa in the hijrah of two hundred and fifty-one-year-olds in seven Rajabs and his seventeen-year-old kingdom, soon after he died and the kingdom given to Teuku Syik Ali Johan Perkasa on the hijrah of one thousand two hundred seventy-one years on seven Safar in the state Samalanga six Mukim Council and in its border, to the west Ulim river, to the north unlimited, to the east Jumpa River, to the south unlimited. And his second son from Teungku Shik Geumbak Johar Perkasa became Teuku Nyak Adek. So, on hijrah one thousand two hundred and eighty-five (five) years on the fourteenth day of Muharram he died, [then] the kingdom was given to his son from Teuku Syik Ali Johan Perkasa who was Teuku Fardan who then took the title Teuku Syik Fardan. He safeguards the Shari'a law in Nanggroe Samalanga VI Mukim, as well as marriage, fasakh and divorce laws. This adat law cannot be violated by the village head and elders. As well the people cannot violate the rules of Teuku Syik Fardan in Nanggroe Samalanga six mukim who returned as Daulat Syah Alam. End. Amin. $\left.{ }^{24}\right]$

The second version of Sarakata Samalanga explained the genealogy of raja Samalanga's descendants based on Tun Seri Lanang's heir. This genealogy can be referred to based on Figure 1.

Dutch sources which were recorded in Dagh-Register explained the outcome of the meeting between a number of Dutch representatives and Seri Paduka Tuan Seberang, affirming yet another name which was used to refer to the position or appoinment of Tun Seri Lanang in Aceh i.e. Sirij Paducca Tuan. ${ }^{25}$ Tichelman in his writing, "Een Atjehsche Sarakata" ${ }^{26}$ commented on Sarakata Samalanga which was dated 1022 H equivalent to 1613 M, i.e. on the sixth year of Sultan Iskandar Muda's rule. In this year indeed Aceh had launched an expedition to Johor and after it was successfully annexed in June 1613, the sultan of Johor and his dignitaries were subsquently brought to Aceh. ${ }^{27}$ With reference to Tichelman's notation, Ito explained: 
One indigenous source of information for this is the class of indigenous documents bearing the ruler's seal. Two such documents related to grants of land, were first brought to our attention by Tichelman. One of them, judging from the royal seal in it, was probably issued by Sultan Jamal al-Alam Badr al-Munir (1703-1726). The other dates from the 19th century. In both these Sarakata, although separated by a long period of time, is recorded that in 1613 Iskandar Muda granted a certain Orang Kaya Tuk Bahra an area consisting of six Mukim in Samalanga on the north coast. Later during the reign of Safiyyat al-Din this Orang Kaya, referred to by his title Seri Paduka Tuan Seberang,

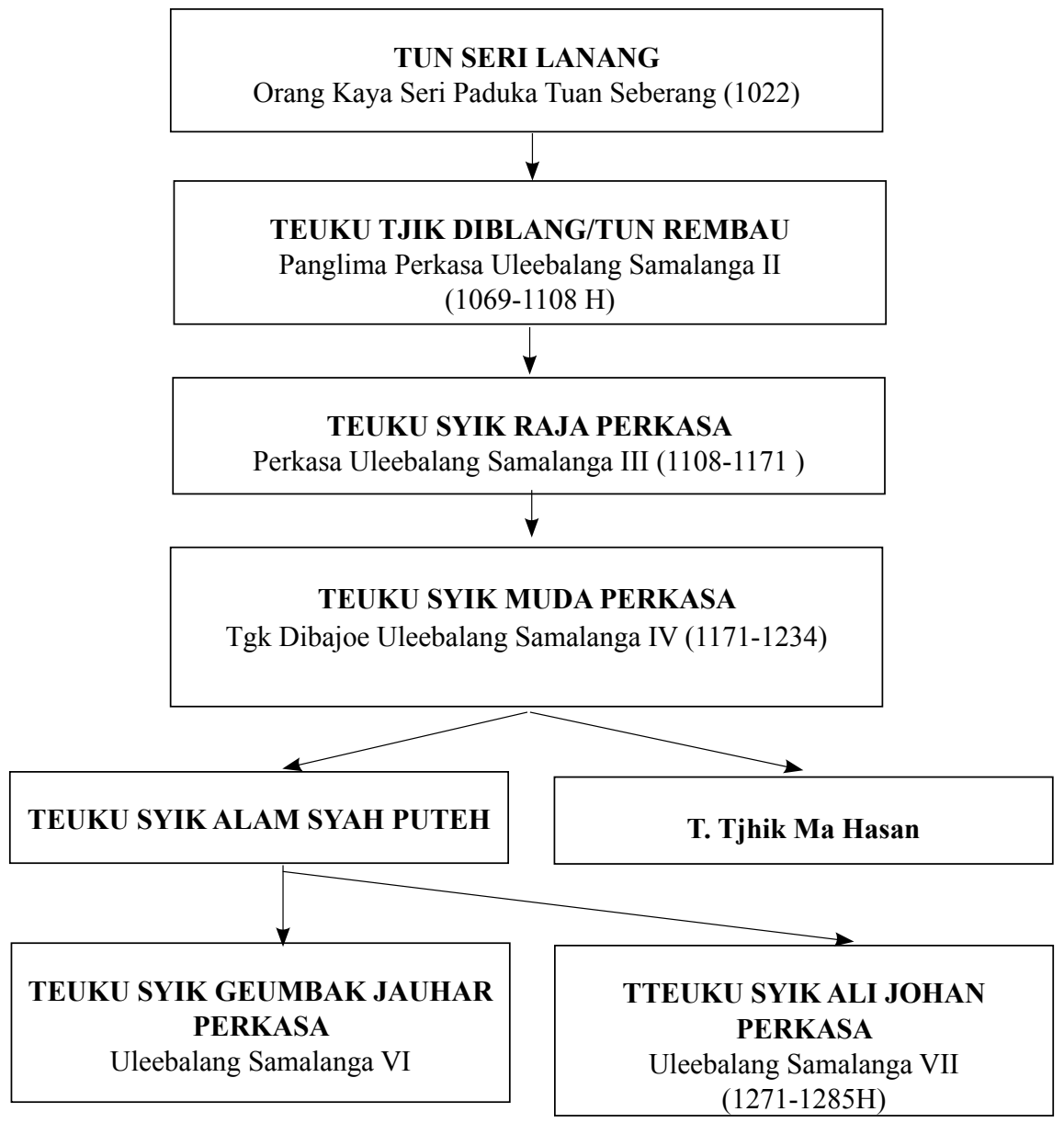

Figure 1 The genealogy of raja Samalanga's descendants based on the second version of the manuscript Sarakata Samalanga published by Sultan Ibrahim Mansur Syah (1251-1286H/1836-1870 M). 
was confirmed in his authority over the territory. After his death in 1658, his son Teuku Ci' di Blang succeeded him. ${ }^{28}$

Based on this document, Takeshi Ito contended that the Sarakata "... was probably issued by Sultan Jamal al-Alam Badr al-Munir (1703-1726). ${ }^{29}$ But through the investigation that was conducted, it was found that the first Sarakata Samalanga was published during the reign of Sultan Iskandar Muda (1607-1636) which was reaffirmed during the ruling period of Sultanah Safiatuddin Syah (1641-1675 M). This idea was based on the statement in the introduction of Sarakata Samalanga as shown below:

Pada hijrat Nabi sallallahu alaihi wasallam seribu dua puluh dua tahun [1022], tujuh belas hari Rabiul al awwal yaum al jum'ah ba'da salat pada zaman paduka seri Sultan Iskandar Muda Johan berdaulat zillallah fil al alam ...

[At hijrah the Prophet sallallahu alaihi wasallam one thousand twenty-two years, seventeen days Rabiul al-awwal a day of Jumaat after prayer, in the period of Paduka Seri Sultan Iskandar Muda Johan sovereign zillallah fil al-alam .... $]^{30}$

Then in the concluding statement of Sarakata Samalanga it was stated again:

Maka kemudian daripada zaman paduka seri Sultan Taj al alam Safiyyat al din Syah berdaulat zill Allah fi alam pada masa itulah Orang Kaya Tuk Bahra Seri Paduka Tuan Seberang, maka mohon hadharat Shahi Alam kehendak bersalin daftar sarakata Majlis negeri Samarlanga negerinya serta dengan perenggannya [batasannya] u barat krueng [sungai] Ulim u baroh [utara] $u$ baroh habeh [seluruhnya] u timu krueng Jeumpa, u tunong [selatan] habeh. Inilah perenggan negeri Samarlanga enam mukim.

[So then from the time of Sultan Taj al-Alam Safiyyat al din Syah berdaulat zill Allah fil alam, on that day, Orang Kaya Tuk Bahra Seri Paduka Tuan Seberang then request to Shah Alam to give to copy of the list of the state Samarlanga State Council's and its border to the west Ulim river, to the north unlimited to the east Jumpa river, to the south unlimited. This is the border state of Samarlanga six mukim. ${ }^{31}$ ]

Most likely, this Sarakata Samalanga was arranged by a religious scholar who was the sultan's adviser. This matter was proven based on the foreword to the Sarakata which appeared as below: 
Pada hijrat Nabi sallallahu wasallam seribu dua puluh dua tahun, tujuh belas hari Rabiul al awwal yaum al jum'ah ba'da salat pada zaman paduka seri Sultan Iskandar Muda Johan berdaulat zillallah fil al alam, tatkala itu insyaAllah taala dengan berkat syafa'at Nabi kita Muhammad Rasul Allah [sallallahu] alaihi wasallam dan dengan berkat segala ambiya walmursalin dan dengan berkat keramat sahabat yang keempat dan dengan berkat 'izzat Sultan al arifin sayyid syeikh Muhyi al din Abdu al Qadir Jilani [pendiri tarikat Qadiriyah] dan dengan berkat segala qutb [qutub merupakan tingkatantingkatan tertinggi dalam urutan jenjang dunia tasawuf] al rabbani wa ghawth [ghawth juga merupakan tingkatan tertinggi dalam urutan jenjang dunia tasawuf] al samadani dan dengan berkat sempurna segala aulia Allah as shalihin wal abidin min masyarikil ardh ila maghaaribiha dan dengan berkat doa paduka marhum sekalian dan dengan berkat apuah [apuah adalah bahasa Aceh yang artinya adalah usaha] marhum sayyid al Mukammal [Sultan Sayyid al Mukammal adalah nama lain dari Sultan Alaidin Riayat Syah (1588-1604M) nenda Sultan Iskandar Muda.

[At the hijrah the Prophet sallallahu wasallam one thousand twenty two years, seventeen days Rabiul al-awwal after jumat prayer, in the time of Sultan Iskandar Muda Johan berdaulat zillallah fil al-alam, with the blessing and thanks of our Prophet Muhammad the Messenger of God and with blessings from all the prophet of walmursalin and with the blessing of the four friends and with the blessings of' izzat Sultan al-arifin sayyid syeikh Muhyi al-din Abdu al-Qadir Jilani [founder of Qadiriyah tarekat] and with the blessings of qutb [qutub are the highest levels in the tasawuf world order] al-rabbani wa ghawth (ghawth is also the highest level in the tasawuf world order) al-samadani and with the perfect blessing of all aulia Allah as shalihin wal abidin min and with the blessings of all Almarhums and Marhum Sayyid al-Mukammal [Sultan Sayyid al Mukammal is another name of Sultan Alaidin Riayat Syah (1588-1604M) grandfather of Sultan Iskandar Muda. ${ }^{32}$ ]

After praises were made, as were normally done, in statements in the Sarakata, the following was stated:

Maka adalah paduka Seri Sultan Iskandar Muda Johan berdaulat zillallah fil alam tatkala semayam atas takhta kerajaan yang di atas kerusi daripada emas itu yang sepuluh mutu yang bertepikan ratna mutu manikam yang berumbai-rumbai mutiara dikala dewasa itulah sabda hadrat syahi alam kepada Orang Kaya Tuk Bahra [Datuk Bendahara] dan kepada Penghulu Kerkun (k-r-k-w-n) Katibul Muluk Seri Indera Sura dan kepada Karkun Seri Indera Muda yang di balai besar serta surat tanda akan seperti dalam sarakata yang di balai besar. 
[So is the king of Sultan Iskandar Muda sovereign zillallah fil alam when heading towards the royal throne on a ten-seated gold seat that defines the quality of the pearl-tassels in the millennium, that is the word of the Shah Alam to Orang Kaya Tuk Bahra [Datuk Bendahara] and to the Penghulu Karkun (krkwn) Katibul Muluk Seri Indera Sura and to Karkun Seri Indera Muda who are in the hall and the verdict will be as in the words in the big hall. ${ }^{33]}$

As previously mentioned, this Sarakata was published again during the reign of Sultanah Safiatuddin Syah. This matter recurred during the reign of Sultan Ibrahim Mansur Syah (1836-1870) which proved that Tun Seri Lanang lived long and was highly influential in the reign of the kingdom of Aceh Darussalam. Apart from being presented the region which was under the control of Samalanga, Tun Seri Lanang was also entrusted to head a number of administrative departments at the centre of governance of the kingdom of Aceh Darussalam. A number of other Orang Kaya's were also granted their own regions of control. Orang Kaya Maharaja Seri Maharaja Panglima Polem (step brother of Sultanah Safiatuddin Syah) was granted control of the region with 22 counties while Orang Kaya Laksamana Malem Dagang was granted the region in Meureudu, bordering the region of Samalanga. Orang Kaya Mangkubumi was then granted the region of Lhokseumawe while Orang Kaya Laksamana Khuja Bintan obtained the region of Deli (Northern Sumatera). ${ }^{34}$

Apart from the two versions of Sarakata Samalanga above, one more genealogy of Tun Seri Lanang, which was published by Aceh's Cultural Board in $1958,{ }^{35}$ was also found. According to this genealogy, Tun Seri Lanang sired two children, i.e. Tun Jenal and Tgk Chik in Blang (16581697). ${ }^{36}$ But based on Sulalat-us-Salatin which was managed by A. Samad Ahmad, Tun Seri Lanang was said to have sired three boys and a girl with his wife Tun Aminah; that is Tun Anum, Tun Jenal, Tun Mat Ali and Tun Gembuk. ${ }^{37}$ In Sulalat-us-Salatin it was also mentioned that Tun Seri Lanang had a child with one of his mistresses during the duration of his stay in Aceh. The child's name was Tun Rembau who was conferred the title Seri Paduka Tuan; previously he was Panglima Bandar Darussalam, ${ }^{38}$ a position that was once held by Tun Seri Lanang. From another perspective, Ito said that "Encik Rambau" was the son of Orang Kaya Seri Paduka Tuan Seberang and from 1652-1653 he was appointed as Panglima Deli by Sultanah Safiatuddin Syah. ${ }^{39}$ It can be explained that Encik Rembau was Tun Rembau as mentioned in Sulalat-us-Salatin which was managed by A. Samad Ahmad. According to Sulalat-us-Salatin, Tun Rembau married the daughter of Perak's Vizier and 
sired four children, notably Tun Aceh, who was conferred the title Bendahara Darul Salam, Tun Perak, the title Raja Indera Bongsu, Tun Jiba, the title Tun Wara Nangsa; another daughter who was the wife of Seri Paduka Megat Mansur, and who had become the Panglima Bandar of Aceh. ${ }^{40}$ Apparently, "Encik Rambau" or Tun Rembau was not just married to the daughter of the Bendahara of Perak as the manuscript Sulalat-us-Salatin explained that “... Tun Rembau had sired many more children which we have not mentioned, in case people will get bored listening to this; it was found that the Datuk had as many as fifty grandchildren". ${ }^{41}$

Discord among Tun Seri Lanang's heirs in Samalanga occurred at the end of the 1870's, when some of them cooperated with the Dutch while others resisted them. In the colonising process the Dutch reacted by attacking Samalanga starting in August until October 1877. Resistance from the people of Samalanga towards the Dutch was so strong that it caused an injury to the left eye of the commander of the Dutch army, General Van der Heijden, after being struck by a bullet from Aceh's army. Nevertheless, with the cooperation of some of Tun Seri Lanang's heirs led by Teungku Chik Muda Boegih, son of Teuku Chik Muda Hasan, who intended to wrest the position of the king of the state of Samalanga from his relation Teuku Chik Ali Johan Perkasa, ${ }^{42}$ hence on February 1901 the Dutch successfully controlled Aceh's defence bastion in Samalanga.

Actually since 1877 two administrations were formed in the state of Samalanga. The group led by Teuku Chik Muda Boegih ruled under Dutch protection until 1896. His position was inherited by his son Teuku Chik Mohd Ali Basjah. It was only in February 1901that the Dutch successfully controlled Samalanga after occupying Aceh's defence bastion in Bateeiliek, Samalanga. Thereafter, the administration of the state of Samalanga was fully controlled by Teuku Chik Mohd Ali Basjah until 1920 and, subsequently, by his grandson Teuku Chik Muhammad Baharom Syah (1920-1946). ${ }^{43}$ Another group of Tun Seri Lanang's heirs who were loyal to the sultan of Aceh, Sultan Muhammad Daud Syah, led by Teuku Syik Ali Johan Perkasa, was eventually captured by the Dutch in March 1907; they were then exiled together by the Dutch to Batavia. ${ }^{44}$

The name Tun Seri Lanang was better known as a figure in the Malay literary world. ${ }^{45}$ In the foreword of a number of Sulalat-us-Salatin's manuscripts, it was mentioned that Tun Seri Lanang's original name was Tun Muhammad or Tun Mahmud. ${ }^{46}$ It was stated that he was conferred the title Bendahara Paduka Raja and was married to Tun Aminah, daughter of 
Tun Kadut and granddaughter of Seri Amar Bangsa Tun Pang; he was also known by some as "Datuk Bendahara yang ke Aceh. ${ }^{47 "}$ "Teuku Iskandar said that Sulalat-us-Salatin was composed by Bendahara Paduka Raja or Tun Seri Lanang himself, and it was also indicated that he was in actual fact not a religious scholar. The name Bendahara Paduka Raja, as mentioned by Teuku Iskandar, was a title for Johor's palace dignitary which was conferred by the sultan of Johor. After Tun Seri Lanang's stay in Aceh, Sulalat-usSalatin recorded that the name of Tun Seri Lanang was known in Johor as "Datuk Bendahara yang ke Aceh" ${ }^{48}$ But in Aceh itself, since he was from "seberang" (state and appellation given to the Malay Peninsula), hence to Aceh's society, Tun Seri Lanang was better known as Tuan Seberang. After his appointment as a dignitary of the kingdom of Aceh the name and title that were conferred on him was "Orang Kaya Tok Bahra (Bendahara) Seri Paduka Tuan Seberang". ${ }^{49}$ Actually the mention of Tok or Datuk in Aceh was employed in a specific way for dignitaries who originated from the state in the Malay Peninsula and the practice of conferring this title only began in Aceh in the 17th century.

Other writers who also supported the position of Tuan Seberang as a dignitary of Aceh and Tun Seri Lanang was Suzana Hj. Othman, ${ }^{50}$ while Tgk A.K. Jakobi, a historian from Aceh in his book Aceh dalam Perang Mempertahankan Proklamasi Kemerdekaan 1945-1949 dan Peranan Teuku Hamid Azwar Sebagai Pejuang (Aceh at War in Defending the Proclamation of Independence 1945-1949 and the Role of Teuku Hamid Azwar as a Warrior) stated that Teuku Hamid Azwar who was raja Samalanga's youngest brother (1920-1948) was the direct descendent of Datuk Bendahara Seri Lanang, ${ }^{51}$ In addition, the Seminar on the Town Culture of Aceh in 1958 also debated on the presence and role of Tun Seri Lanang in Aceh. The outcome of this seminar revealed that Tun Seri Lanang indeed lived in Aceh during the 17th century and was the head of the state of Samalanga with the title Orang Kaya Seri Paduka Tuan Seberang. This seminar also confirmed the genealogy of Tun Seri Lanang in Aceh which was outlined by Teuku Raja Sabi based on Sarakata Samalanga. ${ }^{52}$

The Sulalat-us-Salatin that was managed by A. Samad Ahmad did mention that "Tun Muhammad, also known as Bendahara Paduka Raja, was married to Tun Aminah daughter of Tun Kadut, granddaughter of Seri Amar Bangsa Tun Pang; who was being referred to as Datuk Bendahara yang ke Aceh". Clearly, "Datuk Bendahara Muhammad Sari Lanang" as mentioned by A.K. Jakobi and "Datuk Bendahara yang ke Aceh" in A. Samad Ahmad's 
Sulalat-us-Salatin, was the same individual, namely Tun Seri Lanang. The expression "Bendahara yang ke Aceh" ostensibly was inserted by the writer or by a scribe later on who perhaps might have descended from Tun Seri Lanang himself after the latter's demise. ${ }^{53}$

Tun Seri Lanang or "Tuan Seberang" played an extremely important role as a dignitary of Aceh, as head of the state as well as head of the army of the kingdom of Aceh Darussalam especially in Samalanga. This important duty was only given to prominent people entrusted by the sultan and his enforcers in the sultanate district or the whole world long time ago. ${ }^{54} \mathrm{His}$ position which was referred to as "Uleebalang" functioned to maintain public order according to custom by implementing rules and imposing punishment on those who had committed any wrongdoing. Through the position that he held, Tun Seri Lanang received a number of sources of income in order to sustain his life and family's as a dignitary of Aceh.

\section{THE ROLE OF TUN SERI LANANG IN THE ADMINISTRATION OF THE KINGDOM OF ACEH}

Apart from being head of state (first commander) of Samalanga, Tun Seri Lanang during the reign of Sultan Iskandar Thani (1636-1641) also held the position of Orang Kaya Maharaja Lela (Prime Minister) in the kingdom of Aceh. He held this position until 1644, i.e. during the early reign of Sultanah Safiatuddin Syah (1641-1675). Subsequently, Sultanah Safiatuddin Syah granted a new prominent position, Panglima Bandar (Port Master) to Tun Seri Lanang until his demise in 1658.

At the time when Tun Seri Lanang held the position of Orang Kaya Maharaja Lela and Panglima Bandar, Malay politics around the Straits of Malacca was highly unstable, in particular after the Dutch had successfully seized Malacca from the Portuguese in 1641. In this matter, a writer, Sher Banu Al Khan, explained Aceh's political situation after the conquest of Malacca as follows:

After 1641, Aceh had to deal with a new, uncomfortable political reality, where the Dutch were now the master of Melaka and a reemergent Johor, an ally of the Dutch, was set to challenge Aceh's pre-eminent position as the leading Malay polity. As for the Company, the question is: why did Van Diemen fail to obtain Aceh's help, clearly the preferred ally and the strategic advantage he had counted on, for a short, successful campaign against the Portuguese. Although the Company finally conquered Melaka without Iskandar Thani's 
help, this botched alliance caused the Company dearly nearly leading to the abandonment of the whole campaign. ${ }^{55}$

Tuan Seberang or Tun Seri Lanang played an important role in ensuring that integrity of the adminstration of the kingdom of Aceh during this critical period, as documented by Commissioner Arnold de Vlamingh Van Oudtshoorn who had visited Aceh from 13 July 1644 to 29 October $1644 .{ }^{56}$ Based on this Dutch source, it is clear that in executing his power, Sultanah Safiatuddin Syah was aided by a number of Orang Kaya who played important roles. One of the extremely influential Orang Kaya was Datuk Bendahara Seri Paduka Tuan Seberang, who at that time performed his duty and wielded power as Orang Kaya Laksamana Maha Raja Lela. ${ }^{57}$ In that documentation, the position of Tuan Seberang was recorded as Sirij Paducca Tuan while the position of Orang Kaya Laksamana Maha Raja Lela was noted as Maradia Lilla. Commissioner Arnold de Vlamingh van Oudtshoorn also said that Sirij Paduka Tuan and Maradia Lilla were the Commander and Governor respectively who managed the affairs of foreigners and became prominent personalities in the administration of the kingdom of Aceh. ${ }^{58}$ This documentation also clarified that Sirij Paducca Tuan and Maradia Lilla was the same person and he was believed to have originated from the Malay Peninsula; this was further reaffirmed by Takeshi Ito's study which stated that both these positions were actually held by "a man of Malay origin". ${ }^{59}$ As intimated earlier, in Aceh the rank of Orang Kaya Seri Paduka Tuan Seberang was a specific title given to Tun Seri Lanang who had hailed from "Seberang" (Malay Peninsula).

The important role of Sirij Paducca Tuan or Maradia Lilla in the kingdom of Aceh Darussalam's leadership was also recorded in other Dutch documents. For example, in the document of Dagh-register Commissioner Van Pieter Sourij recorded that on 16 July 1642 he had an audience with Sultanah Safiatuddin Syah to solve the issue of the purchase of a precious jewel that was requested by the late husband of Her Majesty, Sultan Iskandar Thani. Pieter Sourij, at that time, was a special messenger to the Governer General of Dutch East Indies, Antonio van Diemen (1 January 1636-19 April 1645) in Batavia. In handling this issue, Sultanah Safiatuddin Syah who was asked by the Dutch representative to make her appearance in order to discuss the request of a precious jewel by her husband stated that she was prepared to receive Pieter Sourij with support from Sirij Paducca Tuan (Tun Seri Lanang); the latter was then holding the position of Maradia Adonne 
Lilla (Orang Kaya Laksamana Maha Raja Lela) ${ }^{60}$ As a matter of fact, at that time, a conflict between the kingdom of Aceh and the Dutch occurred over the purchase of a precious jewel requested by Sultan Iskandar Thani from Dutch traders before the demise of His Majesty; this resulted in the Dutch sending Commissioner Pieter Sourij to meet Sultanah Safiatuddin Syah in order to demand payment for the precious jewel that was requested by her late husband.

According to Pieter Sourij, the first shock he received a week later was when Sirij Paducca Tuan (Tun Seri Lanang) appraised the jewel at a rather low and illogical price, i.e. 5,900 tael from the actual price which was fixed by the Dutch at 15,000 tael. ${ }^{61}$ The Dutch representative reacted by launching a protest on the decision made by Orang Kaya Seri Paduka Tuan Seberang because he failed to offer a reasonable price. Furthermore, Pieter Sourij also took action to pressure Aceh so as not to burden the Dutch by cancelling the purchase of the jewel that was requested by Sultan Iskandar Thani. And yet, the kingdom of Aceh Darussalam that was represented by the wise and resolute Sirij Paducca took a stand by insisting that although Sultan Iskandar Thani himself had requested the jewel, His Majesty had "passed away (een Coningh naar lastende) and all that he had undertaken had perished with his body." 62

According to Pieter Sourij, Sirij Paducca Tuan was a prominent figure in Aceh who was reticent, frequently feigned illness and always guarded the boundary of diplomatic relations between the kingdom of Aceh Darussalam and the Dutch, notwithstanding the conflict over the purchase of the said jewel..$^{63}$ The firm attitude of Sirij Paducca Tuan or Tun Seri Lanang fitted well with the image that was portrayed in Aceh's Hadih Maja which reads:

Barangkadum meuhai meuh, ek tjit tabloe. Meunjo peue budhoe han ek hareuga. ${ }^{64}$

[We can buy gold whatever its price; but there's no price for the ability to keep a good attitude.]

Finally, on 3 August 1642 Sultanah Safiatuddin Syah, as a result of the suggestion from Orang Kaya Seri Paduka Tuan Seberang, agreed to buy the jewel at the price of only 10,000 tael, and not at the price that was fixed by the Dutch, that is 15,000 as offered by Pieter Sourij. The payment for this jewel was made by deducting 4000 tael from entrance fees to Dutch ships at the Bandar Aceh Darussalam port and another 6000 tael paid in 
two seasons. ${ }^{65}$ De Vlamingh reported that Tun Seri Lanang stressed that the bargaining process for the price of goods was a common tradition observed in Aceh, and it was not meant to demonstrate Aceh's harshness towards a foreign party ${ }^{66}$ Meanwhile, the agreement on the selling price of the jewel from the kingdom of Aceh Darussalam, as presented by the Orang Kaya Seri Paduka Tuan Seberang to Her Majesty, was part of the efforts of the kingdom of Aceh to maintain the friendship that was forged between Aceh-Dutch. The explanation provided by Orang Kaya Seri Paduka Tuan Seberang was permitted by Sultanah Safiatuddin Syah. ${ }^{67}$ According to the documentation of Dagh-Register again, the diplomatic relations between the kingdom of Aceh Darussalam and the Dutch was indeed threatened by various challenges, but with the wisdom and charisma shown by Tun Seri Lanang the underlying causes of discord between the kingdom of Aceh Darussalam and the Dutch were often remedied through affable and diplomatic means.

At the same time, the Dutch were constantly attempting to weaken Aceh by exerting control over the kingdom. For example, the Dutch took various efforts and tactics so that the Malay states in the Peninsula and in Sumatera such as Perak, Kedah, West Sumatera and North Sumatera disentangled themselves from the power of Aceh. ${ }^{68}$ The crafty measures of the Dutch were carried out through enticements, sometimes with empty threats and often by playing one against another and slander and other times through negotiation and diplomacy. ${ }^{69}$ Facing such a dire political situation, in 1644 Sultanah Safiatuddin Syah decided to reorganize the ruling structure of the kingdom of Aceh with the aim of bolstering political unity in Aceh in order to face the advancing threat of the Dutch. In this process, the position of Orang Kaya Laksamana Maharaja Lela was divided into two parts to ensure that power struggle among the prominent figures in Aceh would no longer happen. This position required that the one in charge, which was all along held by Tun Seri Lanang, manage the defence administration, the kingdom's security and economic (port-related) matters. In this regard, the position of Interior Commander which included the overseeing of the administration of defence and the country's security was accorded to Orang Kaya Laksamana Seri Maharaja (the step brother of Sultanah Safiatuddin) while the position of Panglima Bandar involving the management of port related matters, the main source of economic income of the country, was given to Orang Kaya Seri Paduka Tuan Seberang or Tun Seri Lanang. This matter made Tun Seri Lanang a person, who at one time, held the position of Panglima Bandar in Aceh. 
According to the manuscript Sarakata Samalanga of 1285 H/1868 M, after Tun Seri Lanang died in $1658,{ }^{70}$ the position of Panglima Bandar and the head of the state Samalanga were bequeathed to his son Teuki Syik in Blang who was also known as Tun Rembau. This was meant to show appreciation for services rendered and the immense contribution of Tun Seri Lanang as a prominent figure in the kingdom of Aceh.

\section{CONCLUSION}

Based on the above discussion, it is clear that early Aceh's historiographic sources are able to prove that Tun Seri Lanang was a prominent Malay figure who was brought into Aceh and served till the end of his life as a dignitary of Aceh, using various titles and positions. Among the many titles or positions he held included the Orang Kaya Seri Paduka Tuan Seberang, Orang Kaya Datuk Bendahara Seri Paduka Tuan Seberang, Orang Kaya Laksamana Maharaja Lela and Panglima Bandar during the reign of Sultan Iskandar Thani as well as Sultanah Safiatuddin Syah. All the positions and titles which were conferred illustrate the importance of Tun Seri Lanang's position in the kingdom of Aceh; clearly, although he was an "outsider" to the kingdom of Aceh, he was still given absolute trust to hold important positions in the administration of the kingdom.

Tun Seri Lanang's role in the kingdom of Aceh Darussalam was indeed wide and strategic. Apart from becoming Raja Kenegerian Samalanga, Tun Seri Lanang also played an important role as a dignitary and adviser of the sultan of Aceh given his various names, duties, responsibilities and power. He was also given the honour of being Orang Kaya Datuk Bendahara Seri Paduka Tuan Seberang, the highest and most influential position in the eyes of the Sultan. Tun Seri Lanang was also the fourth Orang Kaya with the title Orang Kaya Laksamana Maharaja Lela and Panglima Bandar who had controlled port related matters during the reign of Sultan Iskandar Thani and Sultanah Safiatuddin Syah. As a centre of rapid economic activity during that period, his position as Panglima Bandar showed the crucial role Tun Seri Lanang had played; essentially as a distinguished individual who had ensured Aceh's stability and rapid economic progress at that time. In short, all the positions held by Tun Seri Lanang enabled him to be known as an outstanding statesman in Aceh, although in general many people only acknowledged him as a writer of manuscripts notably Sulalat-us-Salatin. .

From written sources that were examined, it is undeniable that Aceh 
had only one personality that is Tun Seri Lanang who was called "Tuan Seberang", which explained why this prominent figure did not live in Johor as mentioned by some researchers, among them Leonard Andaya. There were no other dignitaries in the kingdom of Aceh Darussalam who was referred to by this title. This is because the dignitaries hailed from local provinces in the kingdom of Aceh Darussalam and as such it was not possible for them to be referred to as "Seberang", meaning that the origin of the person in question was across the Straits of Malacca. The dignitaries selected from Aceh's indigenous people were better known with other apellations such as Panglima, Ja, Datuk and others. Among local Aceh dignitaries who were contemporaries of Tun Seri Lanang included Panglima Polem, Panglima Mesjid Raya, Panglima Setia Nanta, Ja Pakeh, Panglima Pidie, Ja Puntong, Panglima Pidie, Dato Makudom Sakti etc. Compared to the title Tun Seri Lanang in the Peninsula, the people of Aceh could better recognise the statesmen of both provinces of Aceh and the Peninsula as Tuan Seberang; a dignitary, administrator, politician and outstanding intellectual who became a binder of relationships, political tradition and history between the two Malay provinces of one origin.

\section{AKNOWLEDGMENT}

This article was funded by the Research Universiy Grant 1001/PHUM/816232, 2013-2016. The authors would like to express their gratitude and appreciation to USM for their financial assistance.

\section{NOTES}

1 These prominent religious scholars have produced a huge body of works when they were under the rule of the kingdom of Aceh, for example Hamzah Fansuri with his famous books such as Syair Burung Inggai, Syair Burung Pungguk, Syair Perahu, Syair Dagang, Syair Sidang Faqir, Syair Ikan Tongkol, Syarab al Asyiqin (the drink of those who love God), Al-Muhtadi Ruba'i Hamzah al-Fansuri. Asrar al-Arifina fi Bayan 'Ilm-Al Suluk wal Tauhid (explanation regarding the journey of mysticism and the oneness of God); and writings in the form of famed poetry (syair) such as Rubba al-Muhakkikina, Kashf al-Sirr al-Tajalli al-Subhani and Miftah al-Asrar. See Uka Tjandrasasmita, Sejarah Nasional Indonesia III, Jakarta: PN Balai Pustaka, 1984, pp. 221. Syamsuddin As-Sumatrani and his works, his essays, either in the Malay language/Jawi Miratul Mukminin (mirroring the comparison of believers), Jauharul Haqaaiq (valued truth), Risalatul Baijin Mulahadhatil Muwahhidin Alal Mulhidi $f i$ Zikrillah (observation of those who acknowledge the oneness of God towards those 
who have strayed in remembering Allah), Kitabul Harakah (knowledge of language), Nurul Daqaaiq (light that is pure), Miratul Iman (mirror of faith), Syarah Miratul Qulub (explanantion regarding reflections of the entire heart) Kitab Tazyim (book of flaws), Syar'ul Arifin (path taken by the wise and the learned), Kitabul Ushulut Tahqiq (book of strenthening policies), Miratul Haqiqah (mirror of truth), Kitabul Martabah (book regarding the status of mankind), Risalatul Wahhab (essay regarding the Mighty Giver), Miratul Muhaqqiqin (reflections of the ones proving or establishing truth or falsehood), Tanbihullah (rememberances of Allah). See A. Hasymi, Kebudayaan Aceh dalam Sejarah, Jakarta: Beuna, 1993, pp. 198; Nuruddin Ar Raniry with his works in the Malay language Shiratul Mustaqim (laws pertaining to ritual obligations), Darul Faraid bi Syarhil Aqaid (knowledge regarding the oneness of God/philosophy), Busthanus Salathin fi Zikril Auwalin wal akhirin, Akhbarul Akhirah fi Ahwali Jaumil Qiyamah, Hidayatul Habib fit Targhib wat Tarhib, At Tibyan fi Ma'rifatil Ad-Yan, Asrarul Insan fi Ma'rifatir Ruhi war Rahman, Lathaiful Asrar, Nubzatun fi Da 'wazzil ma'a Sahibin, Maul hayati li ahlil mamati, Syafa-ul Qulub, Umdatul I'tiqad, Djahawirul Ulum fi Kasyfil Ma'lum, Bad-u Khalqis Samawati wal Ardli, Hudyjatush Shadik li Daf'iz Zindiq, Fathui Muhil Alal Mulhidin, Ala lam'u fi Tafkiri man qala bi khalqil Quran, Tambihul' awamili fi tahqiqia kalami finawafil, Shawarimush Shadik li Qath'iz Zindiq, Rahiqul Muhammadiyah fi Thariqish Shufiyah, see Ibid., pp, 201. Syeikh Abdurrauf al-Fansuri as-Singkili with his works Turjumanul Mustafiid explanation of the first al-Qur'an in the Malay language which was translated from the explanation given by Anwaru Tanzil wa Asrarut Takwil, essay by Abdullah bin Umar bin Muhammad Syirazy Al Baidlawy is better known with the name of the explanation of Baidlawy, Miraatut Thullab (book of laws pertaining to ritual obligations) regarding a comprehensive knowledge of laws that cover all aspects of the field of law, Umdatul Ahkaam, also book/knowledge of laws/pertaining to ritual obligations, Umdatul Muhtajin Ha Suluki Maslakil Mufradin (knowledge of divinity/philosophy) in this book Syeikh Abdul Rauf documented a large number of religious teachers at the place where he was their student, Kifayatul Muhtajin (knowledge of mysticism), Daqaiqul Huruf (the secret of letters), Hidayatul Balaghah 'ala Jum'atil Mukhashamah (book of Islamic laws regarding evidence, giving of testimony and false oaths), Bayan Tajalli (knowledge of divinity), Sya'ir Ma'rifat (essay in the form of poetry, debating the matter on the oneness of God/tariqat), Kisah Iskandar Zulkarnain, Hikayat Raja Badar, Babun Nikah, Saqyur Rasul, Mu'ammadul I'tiqad, Hidayatul Mubtadi bi Fadllillahil Muhdi.

2 There are several articles that have been produced discussing the history of life of Tun Seri Lanang, for example Arba'iyah Mohd Noor, "Tun Seri Lanang: Kehidupan dan Pemikiran", Sejarah: Jurnal Jabatan Sejarah Universiti Malaya 13, 2005, pp. 26-49. However, Arbaiyah's writings only look at the perspectives and contributions of Tun Seri Lanang in general. Another study by Johari Talib et al., "Tun Seri Lanang: Dari Istana Batu Sawar ke Naggaroe Acheh Darussalam”, Jurnal Melayu 16 (1), 2017, pp. 32-46 is generally more dependent on secondary sources, especially a book written by Pocut Haslinda who had discussed Tun Seri Lanang without using comprehensive historical references. See Pocut Haslinda H. Teuku Abdul Hamid Azawar, Tun Seri Lanang dan Terungkapnya Akar sejarah Melayu Setelah Empat Abad, Jakarta Timur: Pelita Hidup Insani, 2008. 
3 This book, Ma Bain-as-Salatin, although it was written using Jawi, the Arabic alphabet of writing in the Malay language, was also influenced by some local (Aceh) language. The measurement of this book was $23.5 \times 15.5 \mathrm{~cm}$ each page having eleven lines, where scholars often mentioned the book Ma Bain-as-Salatin as the Council of Aceh or Traditions of Aceh (Adat Aceh). The Traditions of Aceh is better known among scholars than Ma Bain-as-Salatin. This is possible as it is based on the dominant word "Traditions" (Adat) which appeared in the book Ma Bain as-Salatin about 375 times, as well as in the third part of the book titled "Adat Majlis Raja-Raja" and the fourth part "Dustur Adat hasil negeri dan segala kapal niaga", the word "adat" could mean regulations, rules, taxation in the constitution of the kingdom of Aceh. For further information, see M. Adli Abdullah and Azmi Arifin, "Ma Bain-as-Salatin sebagai Sumber Persejarahan Aceh, International Conference on Malay Historiography”, Kuantan, Pahang, Malaysia, 2017.

4 Four manuscripts produced during the kingdom of Aceh in the 17th century which used the title al-salatin were Taj-us-Salatin (1603), Ma Bain-as-Salatin (1607), Sulalat-usSalatin (1612) dan Bustan -us-Salatin (1638). See M. Adli Abdullah, Azmi Arifin, "Ma Baina as-Salatin sebagai Sumber Persejarahan Aceh, International Conference on Malay Historiography”, Kuantan, Pahang, Malaysia, 2017.

5 Snouck Hurgronje defined Hadih Maja as a story or traditions of ancestors which meant various traditions of those who had a long life, especially women, which was defended and mutually associated with popular custom and superstitions. See Snouck Hurgronje, The Achehnese, Leiden: E.J. Brill, 1906, p. 53. On the other hand, a local scholar, Harun al-Rasyid also explained that Hadih Maja was a story that contained various ideal and noble values whose existence should be defended as one local genious source. This is because with the disappearance of Hadih Maja, values embraced by the people of Aceh will lose their humanism when society or a tribe loses its cultural value, hence causing the loss of one's true self. See Harun al-Rasyid. (2009). Memahami Orang Aceh, Bandung: Citapustaka Media Perintis, p. 17.

6 See Appendix 8 book Ma Bain as-Salatin in M. Adli Abdullah. (2017). Sejarah Tun Seri Lanang dalam Kerajaan Aceh dan Peranannya Menguatkuasa Adat Aceh (Tesis Ph.D), Bahagian Sejarah, Pusat Pengajian Ilmu Kemanusiaan, Universiti Sains Malaysia, Pulau Pinang, p. 314.

$7 \quad$ Ibid.

$8 \quad$ Ibid.

9 Ibid.

10 Samalanga was a state situated in the province of Pasai and paid homage to the kingdom of Aceh Darussalam. The province of the state of Samalanga now, part of it is situated in Kabupaten Pidie Jaya and another part in the province of Kabupaten Bireun, Aceh.

11 Sarakata Samalanga (first) 1022 H/1613 M by Sultan Iskandar Muda (1607-1636) and reproduced in $1055 \mathrm{H} / 1644 \mathrm{M}$ during the reign of Sultanah Safiatuddin Syah (16411675), kept by Cut Nyak Naimah.

12 G.Tichelman, 'Een Atjehsche Sarakata (Afschrift van een besluit van Iskandar Muda)', Tijdschrift voor Indische Taal, Land, en Volkenkunde uitgegeven door het Bataviaasch Genootschap van Kunst en Wetenschappen (TGB) 73, 1933, pp. 368-373; Tichelman, Samalangasche Sarakata, TBG 78, 1938, pp. 351-358. 


\section{MALAY LITERATURE VOLUME 30 NUMBER 2 DECEMBER 2017}

13 Aboe Bakar. (1976). Sebuah Sarakata Kerajaan Aceh, Banda Aceh: Pusat Dokumentasi dan Infomasi Aceh, p. 5.

14 Interview with Tgk Badruzzaman Ismail, Head of the Council of Traditions of Aceh (Ketua Majelis Adat Aceh), 4 March 2015.

15 See Takeshi Ito. (1984). The World of the Adat Aceh A Historical Study of the Sultanate of Aceh (Ph.D thesis), Southeast Asian, Centre Faculty of Asian Studies, Australian National University, p. 292.

16 Ibid., p. 292.

17 Ibid., p. 328.

18 Uleebalang in Aceh was a local controller and who possessed his own province. For further clarification see Takeshi Ito (ed.). (2015). Aceh Sultanate: State, Society, Religion and Trade the Dutch Sources, 1636-1661, Leiden: Brill, p. 16.

19 G. L. Tichelman, Samalangasche Sarakata, TBG, pp. 351-358.

20 In the incident involving Aceh's attack on Johor in 1613 under the leadership of Sultan Iskandar Muda, the capital of Johor, that is Batu Sawar, was destroyed causing the Sultan of Johor, Sultan Alauddin Riayatshah III and all his people including his younger brother Raja Abdullah, Raja Raden as well as the dignitaries of the state of Johor-Pahang notably Raja Husein (Iskandar Thani), Puteri Kamaliah (Protroe Phang), and his Grand Vizier (Bendahara) (Prime Minister) Tun Muhammad, or better known as by his pseudonym "Tun Sri Lanang" to shift to Aceh. See M. Adli Abdullah, "Permata Melayu di Negeri Aceh", Majlis Pengkisahan Sejarah Ketokohan Tun Seri Lanang, Yayasan Warisan Johor, 15 June 2004.

21 William Linehan. (1936). A history of Pahang, Journal of the Malayan Branch of the Royal Asiatic Society 14(2), 125, pp. 1-257.

22 Daniel Crecelius and E. A. Beardow. (1979). A reputed Acehnese Sarakata of the Jamal al-Lail dynasty. Journal of the Malaysian Branch of the Royal Asiatic Society 52(2), pp. 51-66.

23 W. G. Shellabear. (1975). Sejarah Melayu, Siri Kajian Sastera. Fajar Bakti, Petaling Jaya: Fajar Bakti, p. 156.

24 Sarakata Samalanga (second) 1285 H/1868 M during the reign of the Sultan of Aceh, Sultan Ibrahim Mansur Syah (1836-1870), kept by Cut Nyak Naimah binti Teuku Zainal Abidin (heir of Tun Seri Lanang ke 8), Gampong Baru Samalanga, Kabupaten Bireun, Aceh.

25 Sirij Paducca Tuan was the same person as Orangcaiya Maradia Lila. See Dagh-Register off Jounael Gehouden bij den Pieter Sourij, Gedeputeert als Commissaris door d'Ed. Heer Gouverneur General ende d'Ed. Heeren Raad van India in Legatie aen de Coninginne van Atchin, 1642 ff. 568v.-5689r, 581 v.-582r, in Takeshi Ito (ed.), Aceh Sultanate: State, Society, Religion and Trade The Dutch Sources, 1636-1661 (1). Leiden: BRILL, 2015, pp. 176-177, 191-192; Atchins Dach-Register Gehouden bij de Oppercoopman H Pieter Willemsz 1642 [27 Sept - 27 Nov] f. 506v, 517v in Takeshi Ito (ed), Ibid.pp. 230, 254; Journaal of Dagh-Register Gehouden bij den Commissaris Arnold de Vlamingh van Oudtshoorn Geduijrent Sijn aenwijs in Aetchin A 1644, van dato 13 Julij met Jacht Grol, Daeromtrent de Rhede g'aariveert is, tot 29 October Daeraen Volgende, $\mathrm{p}$ t Voornoemt Jacht Weder Over Malacca van Daer Naer Batavia Sijn Verseijlen, f. 574r, 579v, dlm Takeshi Ito (ed), Ibid., pp. 399, 413; Originele missive of Dirck Schouten, 16 Sept. 1655 f. 277v, in Takeshi Ito (ed) Ibid. p. 747; see also Anthony Reid dan Takeshi Ito, 
From Harbor Autocracies to Feodal Diffussion in Seventeenth Century Indonesia: In the Case of Aceh, Sydney Studies in Society and Culture, 1985, p. 203.

26 G.Tichelman, Een Atjehsche Sarakata (Afschrift van een besluit van Iskandar Muda), TBG, pp. 368-373; Tichelman, Samalangasche Sarakata, TBG, pp. 351-358. pp. 368373.

27 G.Tichelman, Een Atjehsche Sarakata (Afschrift van een besluit van Iskandar Muda), TBG, pp. 368-369; G. Tichelman, Samalangasche Sarakata, TBG, pp. 351-358.

28 Takeshi Ito, The World of the Adat Aceh A Historical Study of the Sultanate of Aceh, p. 60 .

29 Ibid.

30 Sarakata Samalanga, 1022 H/1613 M kept by Cut Nyak Naimah binti Teuku Zainal Abidin (heir of Tun Seri Lanang ke 8), Gampong Baru Samalanga, Kabupaten Bireun, Aceh.

31 Ibid.

32 Ibid.

33 Ibid.

34 Tengku H. M Lah Husni. (1975). Lintasan sejarah, peradaban dan budaya penduduk Melayu pesisir Deli Sumatera Timur (1612-1950). Medan: BP. Husny, p. 36.

35 See Appendix 7 The Genealogy of Tun Seri Lanang's Descendants (Salasilah Keturunan Tun Seri Lanang), in M. Adli Abdullah, Sejarah Tun Seri Lanang dalam Kerajaan Aceh dan Peranannya Menguat kuasa Adat Aceh, Tesis Ph.D, p. 261. This genealogy was reproduced based on the original arrangement of Aceh's Cultural Board (Lembaga Kebudayaan Aceh) in 1958 based on the original genealogy arranged by Teuku Tjhik Samalanga endorsed by Teuku Sabi Oelee Glee. Uleebalang terakhir Samalanga Tunong (Selatan).

36 Ibid.

37 A. Samad Ahmad (peny.). (1979). Sulalatus Salatin: Sejarah Melayu. Kuala Lumpur: Dewan Bahasa dan Pustaka, p. 208.

38 Ibid.

39 Takeshi Ito, The World of the Adat Aceh A Historical Study of the Sultanate of Aceh, p. 42.

40 A. Samad Ahmad (comp.). Sulalatus Salatin (Sejarah Melayu), p. 209.

41 Ibid, pp. 209-210.

42 Generall J. B. Van Heutsz. (1939). Peusangan-Samalanga: Batee Ilie 1900-1901. Koetaraja: Atjehsch Leger Museum, 1939, p. 11.

43 Museum Negeri Banda Aceh (ed.). (1958). Silsilah keturunan Datuk Bendahara Tun Muhammad Sarilanang Keujroen Tjhik Negeri Samalanga. Koeta Raja: Lembaga Kebudayaan Aceh.

44 Aboe Bakar. (1979). Sebuah Sarakata Kerajaan Aceh. Banda Aceh: Pusat Dokumentasi dan Informasi Aceh, p. 5.

45 Teuku Iskandar. (1964). Tun Seri Lanang, pengarang Sejarah Melayu, Kuala Lumpur: Dewan Bahasa dan Pustaka.

46 A. Samad Ahmad (Peny), Sulalatus Salatin, p. 208. See also Arba'iyah Mohd Noor. Tun Seri Lanang: Kehidupan dan pemikiran. Sejarah: Jurnal Jabatan Sejarah Universiti Malaya, pp. 29-30.

47 Ibid., pp. 31-33. 


\section{MALAY LITERATURE VOLUME 30 NUMBER 2 DECEMBER 2017}

48 Ibid.

49 See also Tichelman, Samalangasche Sarakata, TBG, pp. 351-358.

50 Suzana Hj. Othman. (2008). Tun Seri Lanang: Sejarah dan warisan tokoh Melayu tradisional. Kuala Lumpur: Media Satria Sdn. Bhd., p. 89.

51 Tgk A. K. Jakobi. (1998) Aceh dalam perang mempertahankan proklamasi kemerdekaan 1945-1949 dan peranan Teuku Hamid Azwar sebagai pejuang. Jakarta: PT Gramedia Pustaka Utama, p. 48.

52 Museum Negeri Banda Aceh (ed.), Silsilah Keturunan Datuk Bendahara Tun Muhammad Sarilanang Keujroen Tjhik Negeri Samalanga. See also M. Isa Sulaiman. (1997). Sejarah Aceh: Sebuah gugatan terhadap tradisi. Jakarta: Pustaka Sinar Harapan, p. 392; M. Junus Djamil. (1968). Silsilah Tawarich Raja-Raja Kerajaan Aceh, Banda Atjeh: ADJDAM-1/lskandar Muda, p. 71; H. M. Zainuddin. (1957). Tarikh Aceh dan Nusantara. Medan: Pustaka Iskandar Muda, p. 68.

53 A. Samad Ahmad, Sulalatus Salatin, pp. 328-329.

54 Teuku Ibrahim Alfian. (1070). Uleebalang di Atjeh menghadapi Belanda pada akhir abad XIX. Jogjakatra, p. 2.

55 Sher Banu A. L. Khan. (2010). Ties that unbind: The abortive Aceh-VOC alliance for the conquest of Melaka (1640-1641). Indonesia and Malay World 38(111), p. 307.

56 Dagh-Register, Journaal of Daghregister Gehouden bij den Commissaris Arnold de Vlamingh van Oudtshoorn Geduijrent Sijn Aenwijs in Aetchin A 1644, Van Dato 13 Julij met het Jacht Grol, Daeromtrent De Rhede g'arriveert is, tot 29en October Daeraen Volgende, P 't Voornoemt Jacht weder Over Malacca Van Daer Naer Batavia Sijn Verseijlen, VOC 1157 f567r, in Takeshi Ito (ed), Aceh Sultanate: State, Society, Religion and Trade, The Dutch Sources 1636-1661), p. 380.

57 Anthony Reid. (2005). An Indonesian frontier: Acehnese and other histories of Sumatra. NUS Press, p. 145.

58 Commissaris Arnold de Vlamingh van Oudtshoorn mentioned that in Dutch it sounded like "Sirij Paducca Tuan voor desen genaemt Maradia Lilla, sijnde Panglima ofte gouverneur der vreemdelingen ende den vierden ofte laetste in rangh der rijcxraden". See Dagh-Register, VOC 1157; Gehouden bij den Commissaris Arnold de Vlamingh Van Oudtshoorn, 1644, in Takeshi Ito (ed.), Aceh Sultanate: State, Society, Religion and Trade The Dutch Sources, 1636-1661, p. 399.

59 Takeshi Ito, The world of the adat Aceh a historical study of the sultanate of Aceh, $\mathrm{p}$. 292.

60 Dagh-Register, Journaal of Daghregister Gehouden bij den Pieter Sourij, Gedeputeert als Commissaris Door d'Ed. heer Gouverneur Generaal Ende d'Ed. Heeren Raad van India in Legatie Aen De Coninginne Van Atchin. VOC 1143 (f555r), in Takeshi Ito (ed.), Aceh Sultanate: State, Society, Religion and Trade The Dutch Sources, 1636-1661, p. 157.

61 Dagh-Register, Journaal of Daghregister Gehouden bij den Pieter Sourij, Gedeputeert als Commissaris Door d'Ed. heer Gouverneur Generaal Ende d'Ed. Heeren Raad van India in Legatie Aen De Coninginne Van Atchin. VOC 1143 (f 571 r - f 571 v), in Ibid., p. 179.

62 Dagh-Register, Journaal of Daghregister Gehouden bij den Pieter Sourij, Gedeputeert als Commissaris Door d'Ed. heer Gouverneur Generaal Ende d'Ed. Heeren Raad van India in Legatie Aen De Coninginne Van Atchin. VOC 1143 (f572r), in Ibid., p. 180. 
63 Dagh-Register, Journaal of Daghregister Gehouden bij den Pieter Sourij, Gedeputeert als Commissaris Door d'Ed. heer Gouverneur Generaal Ende d'Ed. Heeren Raad van India in Legatie Aen De Coninginne Van Atchin. VOC 1143 (f.576R), in Ibid., p. 184.

64 Hasyim M K, Anzib Lamnyong and HM Zainuddin. (1968). Himpunan Hadih Maja (Pusaka Ureung Tuha), Kuta Raja: Anzib, p. 23.

65 Dagh-Register, Journaal of Daghregister Gehouden bij den Pieter Sourij, Gedeputeert als Commissaris Door d'Ed. heer Gouverneur Generaal Ende d'Ed. Heeren Raad van India in Legatie Aen De Coninginne Van Atchin. VOC 1143 (f581R-581v), in Ibid., pp. 191-192.

66 Dagh-Register, Copie Journaal of Dagh-Register Gehouden bij den Commissaris Arnold de Vlamingh van Oudtshoorn 1644 (13 Jul-12 Oct) VOC 1157 f.596R, in Ibid., p. 457.

67 Sher Banu A. L. Khan. (2009). Rule Behind the Silk Curtain: The Sultanahs of Aceh 1641-1699, Ph.D Thesis, Queen Mary: University of London; see also Anthony Reid and Takeshi Ito, From harbor autocracies to feudal diffussion in seventeenth century Indonesia: In the case of Aceh, in Edmund Leach, S. N. Mukherjee and John Ward (eds). (1985). Feudalism: Comparative studies. Sydney: Sydney Association for Studies in Society and Culture, p. 203.

68 Muhammad Said. (1981). Aceh sepanjang abad. Medan: Percetakan dan Penerbitan Waspada, p. 384.

69 A. Hasjmy. (1977). 59 tahun Aceh merdeka di bawah pemerintahan ratu. Jakarta: Bulan Bintang, p. 146.

70 M Adli Abdullah. Sejarah Tun Seri Lanang dalam Kerajaan Aceh dan peranannya menguatkuasa adat Aceh, Ph.D Thesis, p. 213.

\section{REFERENCES}

A. Hasjmy. (1977). 59 Tahun Aceh Merdeka di bawah Pemerintahan Ratu. Jakarta: Bulan Bintang.

A. Samad Ahmad (comp.).(1985). Sulalatus Salatin. Kuala Lumpur: Dewan Bahasa dan Pustaka.

Anthony Reid. (2005). An Indonesian frontier: Acehnese and other histories of Sumatra. Singapore: NUS Press.

Anthony Reid and Takeshi Ito. (1985). From harbor autocracies to feudal diffussion in seventeenth century Indonesia: in the case of Aceh. Sydney Studies In Society and Culture, p. 203.

Aboe Bakar. (1979). Sebuah Sarakata Kerajaan Aceh. Banda Aceh: Pusat Dokumentasi dan Informasi Aceh.

Arba'iyah Mohd Noor. (2005). Tun Seri Lanang: kehidupan dan pemikiran. Sejarah: Jurnal Jabatan Sejarah Universiti Malaya, No. 13, pp. 29-30.

Dagh-Register, Copie Journaal of Dagh-Register Gehouden bij den Commissaris Arnold de Vlamingh van Oudtshoorn 1644 (13 Jul-12 Oct) VOC 1157 f.596R, in Ibid., p. 457. 
G.Tichelman, Een Atjehsche Sarakata (Afschrift van een besluit van Iskandar Muda), TBG, pp. 368-369; G. Tichelman, Samalangasche Sarakata, TBG, pp. 351-358. Generall J. B. Van Heutsz. (1939). Peusangan-Samalanga: Batee Ilie 1900-1901. Koetaraja: Atjehsch Leger Museum.

H. M. Zainuddin. (1957). Tarikh Aceh dan Nusantara. Medan: Pustaka Iskandar Muda. Ito, Takeshi. (2013). The world of the adat Aceh: A historical study of the Sultanate of Aceh. Ph.D Thesis. Australian National University.

Ito, Takeshi (ed.), (2015). Aceh Sultanate: state, society, religion and trade the Dutch sources, 1636-1661. Leiden: BRILL.

M Adli Abdullah, Sejarah Tun Seri Lanang dalam Kerajaan Aceh dan Peranannya Menguatkuasa Adat Aceh. Ph. D Thesis (unpublished). Universiti Sains Malaysia.

M. Isa Sulaiman. (1997). Sejarah Aceh: sebuah gugatan terhadap tradisi. Jakarta: Pustaka Sinar Harapan.

M. Junus Djamil. (1968). Silsilah Tawarich Raja-Raja Kerajaan Aceh. Banda Atjeh: ADJDAM-1/lskandar Muda.

Museum Negeri Banda Aceh (ed.). (1958). Silsilah keturunan Datuk Bendahara Tun Muhammad Sarilanang Keujroen Tjhik Negeri Samalanga. Koeta Raja: Lembaga Kebudayaan Aceh.

Sarakata Samalanga. (1022 H/1613 M). kept by Cut Nyak Naimah binti Teuku Zainal Abidin (heir of Tun Seri Lanang ke 8), Gampong Baru Samalanga, Kabupaten Bireun, Aceh.

Sher Banu Khan. (2009). Rule Behind the Silk Curtain: The Sultanahs of Aceh 1641-1699. Ph. D Thesis (Unpublished). Queen Mary: University of London.

Sher Banu Al Khan. (2010). Ties that unbind: the abortive Aceh-VOC alliance for the conquest of Melaka (1640-1641). Indonesia and Malay World 38(111), p. 307.

Suzana Hj Othman. (2008). Tun Seri Lanang: Sejarah dan Warisan Tokoh Melayu Tradisional. Kuala Lumpur: Media Satria Sdn. Bhd.

Tengku H. M Lah Husni. (1975). Lintasan sejarah, peradaban dan budaya penduduk Melayu pesisir Deli Sumatera Timur (1612-1950). Medan: BP. Husny.

Teuku Ibrahim Alfian, Uleebalang di Atjeh Menghadapi Belanda pada Akhir Abad XIX, p. 2.

Teuku Iskandar. (1964). Tun Seri Lanang, pengarang Sejarah Melayu. Kuala Lumpur: Dewan Bahasa dan Pustaka.

Tgk A. K. Jakobi. (1998). Aceh dalam perang mempertahankan proklamasi kemerdekaan 1945-1949 dan peranan Teuku Hamid Azwar sebagai pejuang. Jakarta: PT Gramedia Pustaka Utama.

Received: 12 September 2017

Accepted: 15 November 2017 